\title{
EVALUASI KAPASITAS STRUKTUR GEDUNG MEOTEL BY DAFAM JEMBER DENGAN METODE PUSHOVER ANALYSIS
}

\author{
(Studi Kasus: Gedung Meotel by Dafam Jember) \\ Ajeng Safira Kusuma Wardhani ${ }^{1}$, Pujo Priyono ${ }^{2}$, Adhitya Surya Manggala ${ }^{3}$ \\ Program Studi Teknik Sipil Fakultas Teknik Universitas Muhammadiyah Jember ${ }^{1,2,3}$ \\ Jl. Karimata 49, Jember 68121, Indonesia \\ email : ajengsafirawardh@gmail.com
}

\begin{abstract}
The territory of Indonesia, including areas prone to disasters, especially geological natural disasters, is caused by Indonesia's position located at the confluence of 3 (three) world tectonic plates. One of the geological natural disasters that often occurs in Indonesia is an earthquake. The Meotel by Dafam Jember building deserves to be analyzed by the pushover analysis method because it is a multi-storey building that is 10 floors so it must have earthquake resistance as tectonic activity increases in Indonesia. The study was conducted with the help of SAP2000 v.20 software. Through the ATC-40 curve, the target value of the displacement target and the base shear force in the $X$ direction at the control point of the performance point in the modelling are displacements of $0.075 \mathrm{~m}$ and the base shear of $7338.716 \mathrm{kN}$. The value of the roof drift ratio $X$ direction of $0.1928 \%$ is included in the Immediate Occupancy category. The results of the pushover analysis on the structure of Meotel by Dafam Jember show the performance of the building at the level of Immediate Occupancy (IO).
\end{abstract}

Keywords: Meotel Building, Pushover, Performance Point.

\begin{abstract}
Abstrak
Wilayah Indonesia, termasuk daerah rawan bencana, terutama bencana alam geologi, yang disebabkan karena posisi Indonesia terletak pada pertemuan 3 (tiga) lempeng tektonik dunia. Salah satu bencana alam geologi yang sering terjadi di Indonesia adalah gempa bumi. Gedung Meotel by Dafam Jember layak untuk dianalisis dengan metode pushover analysis karena merupakan gedung berlantai banyak yaitu 10 lantai sehingga harus memiliki ketahanan terhadap gempa seiring meningkatnya aktivitas tektonik di Indonesia. Penelitian dilakukan dengan bantuan software SAP2000 v.20. Melalui kurva ATC-40 tersebut didapatkan nilai target perpindahan dan gaya geser dasar arah $\mathrm{X}$ pada titik kontrol tinjauan perfomance point pada permodelan yaitu displacement sebesar $0,075 \mathrm{~m}$ dan base shear sebesar $7338,716 \mathrm{kN}$. Nilai roof drift ratio arah X sebesar $0,1928 \%$ masuk pada kategori Immediate Occupancy. Hasil analisa pushover pada struktur Meotel by Dafam Jember menunjukkan kinerja gedung pada level Immediate Occupancy (IO).
\end{abstract}

Kata kunci: Gedung Meotel, Pushover, Level Kinerja.

\section{PENDAHULUAN}

\subsection{Latar Belakang}

Wilayah Indonesia, termasuk daerah rawan bencana, terutama bencana alam geologi, yang disebabkan karena posisi Indonesia terletak pada pertemuan 3 (tiga) lempeng tektonik dunia yaitu: Lempeng Hindia-Australia di sebelah selatan, Lempeng Eurasia di sebelah barat dan Lempeng Pasifik di sebelah timur. Batas-batas lempeng tersebut merupakan rangkaian gunung api dunia, yang melingkari Samudera Pasifik disebut Pacific Ring of Fire. Rangkaian tersebut $\mathrm{di}$ Indonesia bertemu dengan rangkaian Mediteran yang membentuk gunung-gunung api di Sumatera, Jawa dan Nusa Tenggara. Salah satu bencana alam geologi yang sering terjadi di Indonesia adalah gempa bumi.

Untuk merencanakan sebuah bangunan dengan baik, maka respon struktur terhadap gempa harus dapat diramalkan. Peramalan 
dapat dilakukan dengan menambahkan beban yang berlebih (pushover) pada struktur gedung. Analisis pushover bertujuan untuk mengetahui kinerja struktur setelah terjadi penambahan beban gempa.

Analisis pushover merupakan analisis statik nonlinear bertujuan memperkirakan gaya maksimum dan deformasi yang terjadi guna mengetahui perilaku keruntuhan suatu bangunan. Analisis ini dilakukan dengan cara memberikan beban lateral pada tiap pusat massa lantai yang ditingkatkan secara bertahap (incremental) hingga target displacement tercapai. Pushover analysis dilakukan dengan menggunakan software Structural Analytic Program (SAP) 2000.

Gedung Meotel by Dafam Jember layak untuk dianalisis karena merupakan gedung berlantai banyak yaitu 10 lantai sehingga harus memiliki ketahanan terhadap gempa seiring meningkatnya aktivitas tektonik di Indonesia. Evaluasi kinerja gedung dilakukan untuk mengetahui tingkat zona gempa yang membuat keruntuhan gedung dengan pushover analysis. Hal tersebut melatar belakangi penulis untuk mengangkat judul "Evaluasi Kapasitas Struktur Gedung Meotel by Dafam Jember dengan Metode Pushover Analysis".

\subsection{Rumusan Masalah}

Berdasarkan penjelasan latar belakang pada tugas akhir ini, ditimbulkan uraian rumusan masalah sebagai berikut.

1. Bagaimana performance point berupa nilai displacement dan base shear struktur Motel by Dafam Jember yang didapatkan dari hasil pushover analysis?

2. Bagaimana kinerja struktur Motel by Dafam Jember jika dianalisa dengan metode pushover analysis?

\subsection{Tujuan Penelitian} berikut.

Tujuan dilakukan penelitian ini sebagai

1. Mendapatkan nilai displacement dan base shear struktur Motel by Dafam Jember yang didapatkan dari hasil pushover analysis.
2. Mengetahui kinerja struktur Motel by Dafam Jember dengn metode pushover analysis.

\subsection{Manfaat}

Berdasarkan tujuan penelitian, maka diharapkan penelitian dapat memberikan maanfaat sebagai berikut ini.

a. Mengetahui manfaat mengenai analisis statis nonlinear, yaitu metode Pushover Analysis pada struktur Motel by Dafam Jember.

b. Menambah wawasan mengenai perilaku struktur struktur Motel by Dafam Jember terhadap gempa dengan Pushover Analysis.

c. Menambah pemahaman mengenai aplikasi SAP 2000.

\subsection{Batasan Masalah}

Tugas akhir ini hanya membahas kinerja struktur gedung Meotel by Dafam Jember dengan adanya penambahan gempa melalui penambahan beban pushover dan tidak mencakup perhitungan tangga.

\subsection{Tinjauan Pustaka}

1. Gempa dan Bangunan Tahan Gempa Prager (2006:39) mengemukakan bahwa gempa bumi adalah getaran seismik yang disebabkan oleh pecahannya atau bergesernya bebatuan di suatu tempat di dalam kerak bumi. Menurut Hamblin (1986:338) "earthquake are vibrations of the earth caused by the rupture and sudden movement of rocks that have been strained beyond their elastic limits". Gempa bumi adalah suatu getaran dari bumi yang disebabkan oleh pecahan dan gerakan tiba-tiba dari batuan yang bergerak melebihi batas kelenturannya.

Permasalahan utama dari peristiwaperistiwa gempa adalah:

1. Sangat potensial mengakibatkan kerugian yang besar,

2. Merupakan kejadian alam yang belum dapat diperhitungkan dan diperkirakan secara akurat baik kapan dan dimana terjadinya serta magnitudanya,

3. Gempa tidak dapat dicegah. 
Karena tidak dapat dicegah dan tidak dapat diperkirakan secara akurat, usaha-usaha yang biasa dilakukan adalah: a) menghindari wilayah dimana terdapat fault rupture, kemungkinan tsunami, dan landslide, serta b) bangunan sipil harus direncanakan dan dibangun tahan gempa.

Pengalaman telah membuktikan bahwa sebagian besar korban dan kerugian yang terjadi akibat gempa disebabkan oleh kerusakan dan kegagalan infrastruktur. Kerusakan akibat gempa dapat dibagi dalam dua jenis, yaitu:

1. Kerusakan tidak langsung pada tanah yang menyebabkan terjadinya likuifaksi, cyclic mobility, lateral spreading, kelongsoran lereng, keretakan tanah, subsidence, dan deformasi yang berlebihan,

2. Kerusakan struktur sebagai akibat langsung dari gaya inersia yang diterima bangunan selama goncangan.

Menurut Arfiadi (2006), filosofi bangunan tahan gempa yang diterima luas seperti di bawah ini.

1. Bangunan tidak boleh mengalami kerusakan baik pada komponen struktural maupun non-struktural bila terjadi gempa ringan. Mencegah kerusakan non-struktur oleh gempa ringan

2. Bangunan boleh mengalami kerusakan pada komponen non-struktural tetapi komponen struktural tidak boleh mengalami kerusakan bila terjadi gempa sedang. Mencegah kerusakan struktur dan meminimalkan kerusakan non struktur saat gempa sedang

3. Bangunan boleh mengalami kerusakan baik pada komponen struktural maupun non-struktural tetapi bangunan tidak mengalami keruntuhan sehingga korban jiwa dapat dicegah. Mencegah keruntuhan bangunan atau kerusakan parah akibat gempa besar.

\section{Peta Hazard Indonesia}

Dalam perencanaan bangunan gedung, telah disepakati bersama bahwa peta gempa Indonesia yang baru akan disusun berdasarkan data-data seismisitas paling terkini, hasil-hasil riset terbaru mengenai kondisi seismotektonik di Indonesia, dan menggunakan analisis dengan model 3-D dengan merujuk pada International Building Code 2009 (IBC 2009) dimana IBC 2009 menggunakan probabilitas terlampaui $2 \%$ untuk masa layan bangunan 50 tahun (perioda ulang gempa 2475 tahun) sebagai dasar untuk menentukan gempa desain.

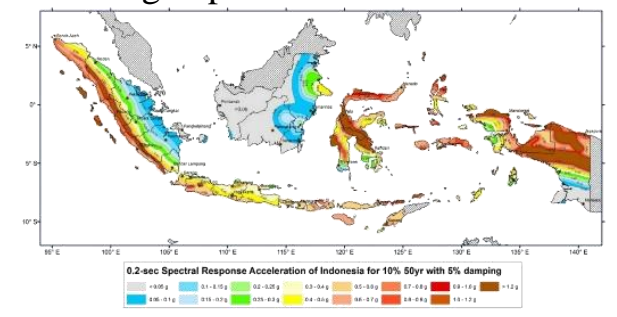

Gambar 1. Peta hazard gempa Indonesia di batuan dasar pada kondisi spektra $\mathrm{T}=0.2$ detik untuk $10 \%$ PE 50 tahun Hasil Studi Tim Revisi Peta Gempa Indonesia 2010.

\section{Pushover Analysis}

Dalam analisis respon struktur digunakan metode pushover. Pushover adalah suatu cara untuk menganalisis struktur dengan beban statik monotonik yang diaplikasikan sepanjang ketinggian struktur dan ditingkatkan sampai simpangan pada puncak atas struktur mencapai simpangan target. Dalam proses pushover, satu sendi plastis akan mencapai kondisi leleh pertama yang kemudian diikuti dengan kondisi leleh pada sendi-sendi plastis lainnya. Hal ini terus berlanjut sampai akhirnya, simpangan pada puncak struktur mencapai simpangan target atau struktur memasuki kondisi tidak stabil (Yehezkiel, 2014).

Menurut SNI Gempa 03-1726-2002, analisis statik beban dorong (pushover) adalah suatu analisis nonlinier statik, yang dalam analisisnya pengaruh gempa rencana terhadap struktur bangunan gedung dianggap sebagai beban statik pada pusat massa masing-masing lantai, yang nilainya ditingkatkan secara berangsur-angsur sampai melampaui pembebanan sehingga menyebabkan terjadinya pelelehan (sendi plastis) pertama di dalam struktur bangunan gedung, kemudian dengan peningkatan beban lebih lanjut mengalami perubahan bentuk pasca-elastik yang besar sampai mencapai target peralihan yang 
diharapkan atau sampai mencapai kondisi plastik.

Metode analisis statik beban dorong merupakan metode dengan pendekatan nonlinier statik, yang dapat digunakan pada struktur bangunan gedung beraturan, dengan karakteristik dinamik mode tinggi yang tidak dominan. Salah satu hasil analisis yang mempunyai manfaat penting yaitu kurva kapasitas.

Tujuan analisa pushover adalah untuk memperkirakan gaya maksimum dan deformasi yang terjadi serta untuk memperoleh informasi bagian mana saja yang kritis. Selanjutnya dapat diidentifikasi bagian-bagian yang memerlukan perhatian khusus untuk pendetailan atau stabilitasnya. (Dewabroto Wiryanto, 2006) Menurut Pranata (2006), tujuan analisis beban dorong adalah mengevaluasi perilaku seismik struktur terhadap beban gempa rencana, yaitu memperoleh nilai faktor daktilitas aktual dan faktor reduksi gempa aktual struktur, memperlihatkan kurva kapasitas (capacity curve), dan memperlihatkan skema kelelehan (distribusi sendi plastis) yang terjadi.

Proses pushover bisa dilakukan dengan prosedur load-controlled atau displacementcontrolled (Ogus. 2005). Prosedur loadcontrolled digunakan jika beban yang diaplikasikan telah diketahui nilainya. Misalnya, beban gravitasi bisa diaplikasikan dalam pushover load-controlled. Prosedur displacement controlled biasanya digunakan jika beban yang bisa ditahan oleh suatu struktur belum diketahui dengan pasti. Sehingga, beban tersebut ditingkatkan sampai struktur mencapai suatu nilai simpangan target.

Analisa pushover dapat digunakan sebagai alat bantu perencanaan tahan gempa, asalkan menyesuaikan dengan keterbatasan yang ada, yaitu:

- Hasil analisis pushover masih berupa suatu pendekatan, karena bagaimanapun perilaku gempa yang sebenarnya adalah bersifat bolak-balik melalui suatu siklus tertentu, sedangkan sifat pembebanan pada analisis pushover adalah statik monotonik.
- Pemilihan pola beban lateral yang digunakan dalam analisis adalah sangat penting.

Untuk membuat model analisis non-linier akan lebih rumit dibanding model analisis linier. Analisis non-linier harus memperhitungkan karakteristik inelastik bebandeformasi dari elemen-elemen yang penting dan efek $P-\Delta$.

Pada perencanaan gedung mekanisme keruntuhan dapat diklasifikasi menjadi dua design yaitu beam sidesway mechanicsm dan column sidesway mechanism. Beam sidesway mechanism yaitu pembentukan sendi plastis direncanakan akan terjadi pertama kali pada ujung-ujung balok terlebih dahulu baru setelah mencapai puncak akan diikuti oleh sendi plastis pada kolom yang didesign terjadi terakhir. Konsep ini biasa disebut sebagai perencanaan daktail parsial dan daktail penuh dalam konsep perencanaan gedung beton. Sedangkan column sidesway mechanism adalah pembentukan sendi plastis pertama kali terjadi direncanakan pada ujung-ujung kolom dasar, pada konsep disebut sebagai perencanaan elastik penuh. Dalam setiap perencanaannya mekanisme keruntuhan struktur yang diharapkan adalah beam sidesway mechanism, karena ketika gaya gempa maksimum terlampaui bangunan masih dapat bediri walaupun ada beberapa properties balok mengalami keruntuhan.

Proses pushover bisa dilakukan dengan prosedur load-controlled atau displacementcontrolled. Prosedur load-controlled digunakan jika beban yang diaplikasikan telah diketahui nilainya. Misalnya, beban gravitasi bisa diaplikasikan dalam pushover load-controlled. Prosedur displacement-controlled biasanya digunakan jika beban yang bisa ditahan oleh suatu struktur belum diketahui dengan pasti sehingga beban tersebut ditingkatkan sampai struktur mencapai suatu nilai simpangan target (Aisyah dan Megantara, 2011).

\section{Batas Kinerja}

Berdasarkan filosofi desain yang ada, tingkat kinerja struktur bangunan akibat gempa rencana adalah Life Safety, yaitu walaupun struktur bangunan mengalami tingkat kerusakan yang cukup parah namun keselamatan penghuni 
tetap terjaga karena struktur bangunan tidak sampai runtuh. Hal penting dalam perancangan berbasis kinerja adalah penetapan sasaran kinerja bangunan terhadap gempa. Sasaran kinerja terdiri dari gempara rencana yang ditentukan (earthquake hazard) dan taraf kerusakan yang diijinkan atau level kinerja dari bangunan terhadap gempa tersebut.

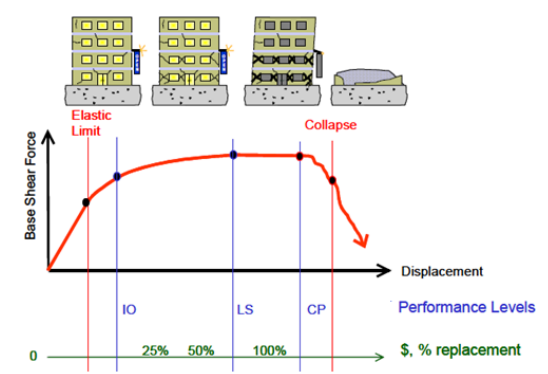

Gambar 2. Ilustrasi Perancangan Berbasis Kinerja

\section{METODE PENELITIAN}

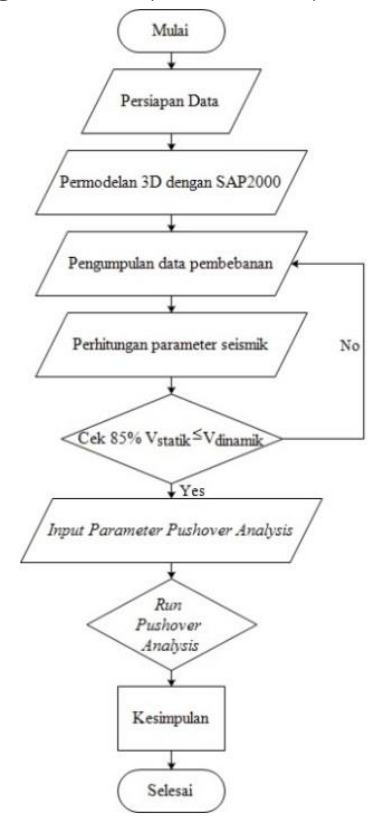

Gambar 3. Flowchart

\section{HASIL DAN PEMBAHASAN}

Hasil analisis pushover yaitu berupa kurva kapasitas dan titik kinerja sesuai dengan metoda spektrum kapasitas ATC-40 kemudian akan didapatkan hasil akhir berupa level kinerja dari suatu bangunan.

Hubungan antara perpindahan lateral lantai atap dan gaya geser dasar digambarkan dalam suatu kurva yang menggambarkan kapasitas struktur dan hal tersebut dinamakan kurva kapasitas (capacity curve). Kurva kapasitas yang didapatkan dari analisis pushover menggambarkan kekuatan struktur yang besarnya sangat tergantung dari kemampuan momen deformasi dari masingmasing komponen struktur. Cara termudah untuk membuat kurva ini adalah dengan mendorong struktur secara bertahap (pushover) dan mencatat hubungan antara gaya geser dasar (base shear) dan perpindahan (displacement) atap akibat beban lateral yang dikerjakan pada struktur dengan pola pembebanan tertentu.

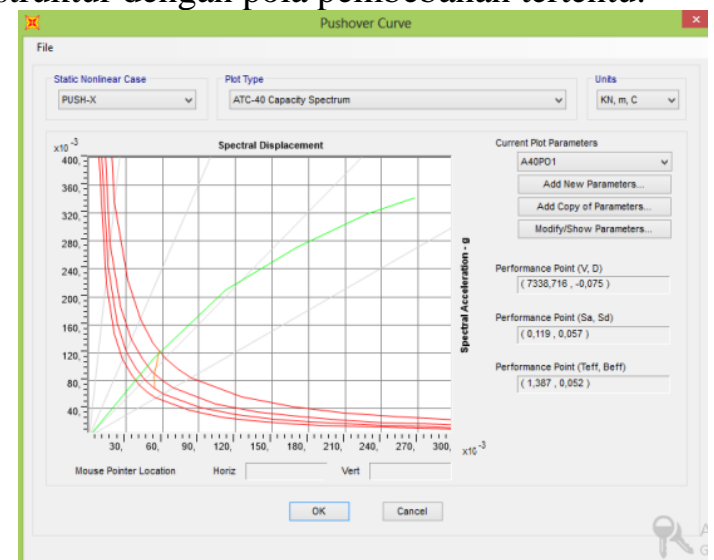

Gambar 4. Kurva kapasitas arah-X dalam format ADRS

Kurva ini menunjukkan bagaimana kekuatan struktur dalam memenuhi suatu beban yang diberikan pada SAP2000 dengan memasukkan nilai $\mathrm{Ca}=0,70$ dan $\mathrm{Cv}=0,168$ dari respon spektrum.

Dari kurva tersebut didapatkan nilai target perpindahan dan gaya geser dasar arah $\mathrm{X}$ pada titik kontrol tinjauan perfomance point pada permodelan yaitu :

$$
\begin{array}{ll}
\text { Displacement } & : 0,075 \mathrm{~m} \\
\text { Base shear } & : 7338,716 \mathrm{kN} .
\end{array}
$$

Berdasarkan metode respons spektrum kapasitas, pelelehan sendi plastis mengakibatkan perilaku struktur arah X pada gempa mengalami in-elastis. Batasan displacement sebesar $0,02 \mathrm{H}$ yaitu $0,778 \mathrm{~m}$, sedangkan target hasil displacement arah $\mathrm{X}$ sebesar $0,075 \mathrm{~m}<0,778 \mathrm{~m}$ sehingga gedung tersebut memenuhi syarat keamanan.

Level kinerja struktur (structural performance levels) ditentukan melalui kriteria 
roof drift ratio yang diperoleh pada saat target perpindahan tercapai dengan rumus :

Roof drift ratio $=\frac{\text { Target perpindahan }(\mathrm{m})}{\text { Elevasi gedung }(\mathrm{m})} \times 100 \%$

Roof drift ratio $=\frac{0,075}{38,9} \times 100 \%=0,1928 \%$

Berdasarkan hasil tabel diatas, yang disyaratkan pada FEMA 356 dan ATC-40 nilai roof drift ratio arah $\mathrm{X}$ sebesar $0,1928 \%$ masuk pada kategori Immediate Occupancy. Kinerja gedung Immediate Occupancy (IO) berarti keadaan kerusakan pasca gempa dimana hanya terjadi kerusakan struktural yang sangat terbatas. Komponen bukan struktur masih ada dan kebanyakan masih berfungsi jika utiliti itu tersedia.

\section{KESIMPULAN DAN SARAN}

\subsection{Kesimpulan}

Pada Tugas Akhir ini didapatkan kesimpulan bahwa :

1. Berdasarkan kurva ATC-40 tersebut didapatkan nilai target perpindahan dan gaya geser dasar arah $\mathrm{X}$ pada titik kontrol tinjauan perfomance point pada permodelan yaitu displacement sebesar $0,075 \mathrm{~m}$ dan base shear sebesar $7338,716 \mathrm{kN}$.

2. Nilai roof drift ratio arah $\mathrm{X}$ sebesar $0,1928 \%$ masuk pada kategori Immediate Occupancy.

\subsection{Saran}

Untuk memperbaiki penelitian ini, sebaiknya dilakukan pemeriksaan struktur gedung di bawah beban gempa dalam kondisi pasca elastik untuk memperoleh tingkat kinerja struktur sesungguhnya dan pemahaman mendetail tentang konsep analisis untuk performance based design disertai data-data yang lebih akurat.

\section{DAFTAR PUSTAKA}

Afandi, N. R. (2010). Evaluasi Kinerja Seismik Struktur Beton dengan Analisis Pushover Menggunakan Program SAP 2000 Studi Kasus: Gedung Rumah Sakit di Surakarta. (Doctoral dissertation, Universitas Sebelas Maret).

Agustina, A. (2016). Analisis Model Keruntuhan Gedung C-Dast II Akibat
Gaya Gempa Dengan Menggunakan Metode Statik Nonlinier. Jember: Universitas Jember.

Aribisma, F., Raka, I. G. P., \& Tavio, T. (2015). Evaluasi Gedung MNC Tower Menggunakan SNI 03-1726-2012 dengan Metode Pushover Analysis. Jurnal Teknik ITS, 4(1), D71-D75.

Indonesia, S. N. (2013). Beban minimum untuk perancangan bangunan gedung dan struktur lain. Badan Standarisasi Nasional.

Indonesia, T. R. P. G. (2010). Ringkasan Hasil Studi Tim Revisi Peta Gempa Indonesia 2010. Jakarta: BNPB, AIFDR, RISTEK, DPU, ITB, BMKG, LIPI, ESDM.

Mamesah, H. Y., Wallah, S. E., \& Windah, R. S. (2014). Analisis Pushover Pada Bangunan Dengan Soft First Story. Jurnal Sipil Statik, 2(4).

Najoan, T.F, dkk. (1999). Peta Zona Gempa Indonesia untuk Penentuan Percepatan Gempa Maksimum di Permukaan. Prosiding Konferensi Nasional Rekayasa Kegempaan.

Nasional, B. S. (2002). Tata Cara Perencanaan Ketahanan Gempa Untuk Struktur Bangunan Gedung Dan Non Gedung. SNI, 1726, 2002.

Nasional, B. S. (2002). Tata Cara Perhitungan Struktur Beton untuk Bangunan Gedung. Badan Standarisasi Nasional (BSN). SNI, 2847, 2012.

Nasional, B. S. (2012). Tata Cara Perencanaan Ketahanan Gempa untuk Struktur Bangunan Gedung dan Non Gedung. SNI, 1726, 2012.

Palupi, A. S. (2015). Studi Kinerja Struktur Gedung Supermall Pakuwon Mansion Phase-1 Surabaya Menggunakan Metode Analisa Pushover. Jember : Universitas Jember.

Suku, Y. Laka. (2015). Evaluasi Kinerja Struktur Gedung Kantor Rektorat Universitas Flores Berdasarkan Pembebanan Gempa SNI 03-1726-2012. Majalah Ilmiah Indikator 17 (2), 78-92.

Umum, D. P. (1983). Peraturan Pembebanan Indonesia untuk Gedung. Bandung: Yayasan Lembaga Penyelidikan Masalah Bangunan (LPMT). 